\title{
Impact of Service Liberalization on the Participation of BRICS Countries in Global Value Chains ${ }^{1}$
}

\author{
O. Biryukova, T. Vorobjeva
}

Olga Biryukova - PhD in Economics, Associate Professor, Faculty of World Economy and International Affairs; Senior Researcher in the Institute of Trade Policy, National Research University Higher School of Economics; 20 Myasnitskaya Street, Moscow, 101000, Russia; E-mail: Olga.Birjukova@mail.ru

Tatiana Vorobjeva - Assistant, Faculty of World Economy and International Affairs, National Research University Higher School of Economics; 20 Myasnitskaya Street, Moscow, 101000, Russia; E-mail: tatiana_vorobeva@bk.ru

\begin{abstract}
This article examines the nature and degree of influence of service liberalization on the participation of the BRICS grouping of Brazil, Russia, India, China and South Africa in global value chains (GVCS).

The inverse relationship between the barriers in infrastructure services and the degree of participation of countries in GVCs was determined using econometric analysis methods. Using data on the structure of trade in goods and services in terms of value added, the situation of developing countries was analyzed using the example of the BRICS in production and service GVCS. China and India are the most deeply integrated countries in the international production and service chains while Russia, Brazil and South Africa participate in the production value chains as suppliers of raw materials and intermediate goods with low added value. However, these countries have a significant potential to expand their participation in the system of international production by improving the infrastructure necessary for the operation of the GVC.

This study of the experience of liberalization in certain service sectors in BRICS countries reveals the positive impact of reducing barriers in maritime, rail and air transportation sectors, as well as finance, for improving the quality and reducing the cost of services. The authors note that in many respects, these effects were the result not only of reducing barriers in services, but also the implementation of a set of measures aimed at increasing the investment attractiveness of countries. The article concludes that the liberalization of infrastructure services industries can become one of the tools for integrating BRICS countries into the GVC. However, this liberalization should be part of a broader development strategy that includes trade and investment policy measures aimed not only at increasing participation in global production, but also overall economic development of the country.
\end{abstract}

Key words: global value chains; value added; service sector; BRICS; liberalization

For citation: Biryukova O., Vorobjeva T. (2017) The Impact of Service Liberalization on the Participation of BRICS Countries in Global Value Chains. International Organisations Research Journal, vol. 12, no 3, pp. 94-113 (in Russian and English). DOI: 10.17323/1996-7845-2017-03-94

${ }^{1}$ The editorial board received the article in June 2017.

Support from the Individual Research Program of the School of World Economy and International Affairs at National Research University Higher School of Economics is gratefully acknowledged, 2017. 


\section{Global Value Chain and Trade Policy in Services}

Services providers play a significant role in the development of global value chains (GVCs). In this case, it is not only about the GVCs in the service sector (the so-called services GVC), but also the GVCs in various industries (production GVC). Services account for more than $40 \%$ of all international trade in terms of value added [Lanz and Maurer, 2015]. These are transport, communications and other business services that are particularly important in the GVCs and international production networks. The production of goods and services is closely interrelated and investment decisions influence the dynamics and geography of international trade flows.

To date, the extent and nature of the participation by developed and developing countries in value chains is significantly different. The former are interested in maximizing the added value created on their territories, while the latter are just beginning to move up the integration steps in the GVCs. However, services play a key role at all stages of involvement of the economy in the GVC system.

The BRICS grouping of Brazil, Russia, India, China and South Africa has a significant industrial potential but continues to remain relatively closed to foreign services providers. Based on the foregoing, it can be assumed that reducing barriers in the services sector could have a positive impact both on the services sector and on the productivity of industrial enterprises. The purpose of this article is to determine the nature and extent of the impact of service liberalization on the participation of BRICS countries in global value chains. This analysis begins with a review of the existing research on this topic and identifies the main approaches to assessing barriers to trade in services. It then evaluates the impact of barriers to trade in services on the degree of involvement of countries in the GVC and examines the features of liberalization of services in the BRICS countries. The analysis concludes by specifying promising areas for increasing the involvement of the BRICS countries in the GVC, taking into account the specifics of national economic development.

\section{Literature Review}

The BRICS economies have strengthened their positions in international trade for more than ten years. This process has attracted growing interest from the academic community as reflected in modern research on the participation of BRICS countries in international trade in goods and services and the prospects for deepening cooperation between the countries in this field.

Sharma and Kallummal [2012] investigated the possibility of concluding a free trade area between BRICS countries using the Global Trade Analysis Project (GTAP) model simulation. They found that the elimination of import tariffs between countries will have a generally positive effect on welfare and macroeconomic indicators for all participating BRICS countries. The growth of trade between them will lead to a negative trade balance for all member countries except Russia. 
Yuan and Zhao [2011] estimated the foreign trade of the BRICS using comparative, statistical and historical analysis. Their study focused on trade in goods and showed a rather high trade dependence for the BRICS countries (led by China, unlike the least dependent Brazil) which will lead to the risk of trade volatility and will negatively affect these economies. Based on their results, most of the exports from China, South Africa and Russia are concentrated in developed countries while exports from India and Brazil are concentrated in emerging markets. As for imports, except for Russia, BRICS countries mainly import from emerging markets. The study concludes that although BRICS members are developing countries with their own problems, they can be complementary and can encompass a new growth model.

Indian researcher Bhattacharya [2016] investigated the relationship between exports and imports of goods and services and economic growth per capita for the BRICS countries using the Granger causality test, FMOLS and DOLS. Bhattacharya concluded that all three variables are cointegrated: exports and imports of goods and services contribute to economic growth per capita in the long term.

De Castro [2012, 2013] has studied the changing patterns of the BRICS's geographical trade in exports in the context of global trade developments over the past decade as well as the development of trade flows between the BRICS and the Triad countries (the U.S., the EU and Japan). He concludes that while the Triad remains one of the most important trading partners for the BRICS, its overall share in the BRICS trade is declining.

Special attention should be paid to work that studies the development of financial services and cooperation between the BRICS countries. Interest in this topic increased significantly after the creation of the BRICS Development Bank. The impact of trade in financial services in the BRICS countries, as well as the potential of financial institutions within the group, is considered in the work of authors including Larionova [2016], Khatun [2016] and Biziwick, Cattaneo and Fryer [2015].

A review of the studies carried out on BRICS participation in international trade reveals a shortage of systematic empirical and theoretical studies of the trade links of BRICS countries in the context of the growing role of global value chains. In particular, insufficient attention is being paid to comparative studies of their participation in the GVCs. As a rule, recommendations for involving countries in global production chains are based on measures and programmes developed by international organizations and western institutions which often do not take account of the specific national economic considerations of different countries. In this regard, the conclusions of this article may be of interest from a research point of view and are of practical importance.

It should be noted that the services sector has a huge potential to contribute to the economic development of BRICS countries, and to their trade and economic relations within the group and with other countries. At the same time, this potential is unfairly overshadowed by the attention of economists to problems in the tertiary sectors of BRICS economies in which considerable trade restrictions remain.

This article offers a comparative analysis of the involvement of the BRICS service sectors in the GVC by reducing barriers to various service industries. Based on data 
on the structure of trade in goods and services in terms of value added, the situation of the BRICS countries in production and service GVC is analyzed and demonstrates that the automatic liberalization of the services sector does not lead to unambiguously positive results for these economies. However, with a consistent national policy aimed at improving the competitive environment in the domestic market, the liberalization of service industries, mainly infrastructure, can become an important tool for inclusion in global value chains.

\section{The Impact of Barriers to Services Trade for Participation in the GVC}

The transformation of the world trade structure requires a revision of trade policy to account for the functioning of the GVC. Research demonstrates a direct relationship between a country's participation in the GVC and the growth rates of its gross domestic product (GDP), the intensity of foreign investment inflow (FDI) and enterprise productivity [OECD, 2013]. Empirical studies have confirmed the positive impact of reducing barriers to trade in services on the factors contributing to the country's integration into the GVC: trade flows, employment, GDP growth rates [Nelson and Taglioni, 2009], productivity and export potential of firms [Knobel, 2012]. Nevertheless, the degree of protectionism in the services sector still far exceeds the barriers that exist in the trade of goods. Greater openness in the service sector could serve as an effective tool for deepening the integration of countries into the system of international production. Research indicates that there is an inverse relationship between the magnitude of barriers in the services sector and the extent of the country's involvement in the GVC. Moreover, since infrastructure services (finance, telecommunications and logistics) play a key role in the operation of production GVCs, liberalization of these industries in the future can have a significant positive impact on the expansion of countries' participation in value chains.

Analysis of existing barriers to trade in services is difficult due to the specific characteristics of services that distinguish them from goods. Because services do not have a material form and their production is inseparable from consumption, it is difficult to apply the customs duties that are usually used when importing goods. Limitations in services can be conditionally divided into direct and indirect forms, which in turn are divided into discriminatory and non-discriminatory limitations (with the latter applicable both to foreign and national service providers). Direct restrictions include quotas and customs fees for the movement of goods necessary for the provision of services, as well as for the movement of individuals. Indirect restrictions include measures that do not directly restrict trade in services but make it difficult to implement: restrictions imposed by the requirements of national legislation to the organizational and legal form of foreign service providers, the system of public procurement, price regulation and others.

It should be noted that not all restrictions in services are barriers to trade, as barriers imply the existence of a real and measurably negative impact on trade in services. 
Thus, the existing methods of quantifying barriers in services trade are divided into methods for measuring the size of the constraints themselves (frequency measurement) and modeling the economic effect from their application (quantitative and price measurement) [Nielson and Taglioni, 2009, p. 37].

To verify this assumption, the Services Trade Restrictiveness Index (STRI), calculated by the Organisation for Economic Co-operation and Development (OECD) for 22 service sectors and covering 44 countries, was selected as a source of information on barriers to international trade. All barriers to import services in each sector are grouped into five main restrictive trade policy measures that are common to all sectors: measures to ensure normative transparency, restriction on the entry of foreign companies into the national market, restrictions on the movement of individuals, measures aimed at restricting competition and other discriminatory measures. Each barrier takes the value of 0 or 1 in its absence or presence respectively, and these values are weighted to take account the specific characteristics of the various sectors. Using these data, the restrictiveness of each sector or service sector of the country as a whole is calculated. To date, the STRI database is one of the most complete and detailed sources of information on barriers to international trade in services.

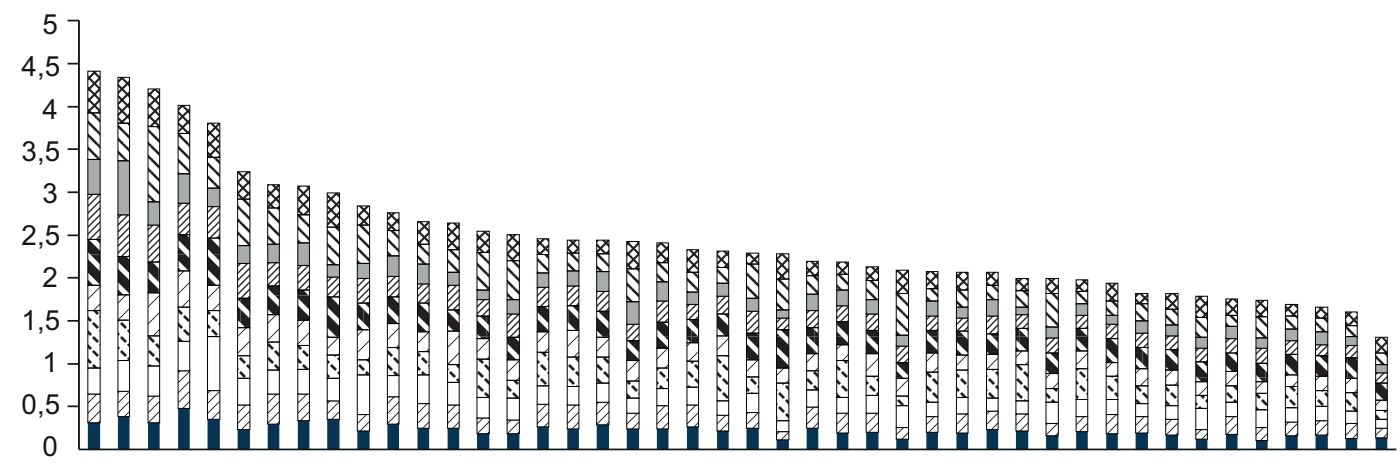

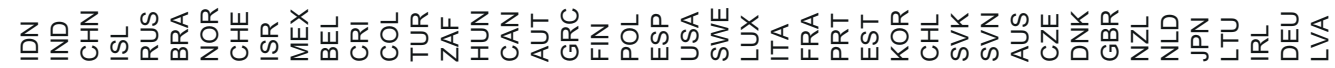

$\square$ Computer
$\square$ Logistics
$\square$ AudioVisual
$\square$ Financial
$\mathbb{N}$ Courrier

Fig. 1. STRI Index Values for Service Sectors, 2015 $\nabla$ Construction

Professional

D Transport

$\square$ Distribution

$\otimes$ Telecommunications

Source: Calculations based on data from OECD Services Trade Restrictiveness Index (April 2017).

Figure 1 shows the value of the level of barriers in various countries by services sector. The graph illustrates that the average level of barriers in developing countries is much higher than in OECD countries, with the most protected sectors being the professional and courier services, as well as key infrastructure sectors such as transport and telecommunications. 
The STRI and information about the share of foreign value added in total exports of each country (forward linkages) and the share of national value added in exports of intermediate or final products from third countries (backward linkages) was used to test the hypothesis that there is an inverse relationship between the level of barriers in the services sector and the country's participation in GVCs. The STRI is calculated using data from 2015, but data on trade in terms of value added are updated every five years and the index of participation in GVCs is based on data from 2011. However, because the process of increasing or reducing barriers in the services sector is quite lengthy, and also because a country's integration into GVCs is gradual as a rule, the difference in time periods of chosen indicators has no significant effect on the conclusions about the required dependencies.

The authors evaluated nine regressions of the form:

$$
\text { GVC Index }{ }_{i}=\alpha_{s, i}+\beta x_{s, i}+\varepsilon_{i, s},
$$

Where GVC Index values participation of a country in GVCs (calculated as the sum of forward and backward linkages), $i \in[1 ; 44]$;

$x_{s, i}$ - the average values of the services restrictiveness index for a particular sector $s$ in a country $i$, calculated for nine service sectors: transport, logistics, finance, telecommunications, distribution, construction, courier services, audiovisual, computer and professional services. Each of the nine regressions was evaluated based on 44 observations. It was found that the size of barriers in telecommunications, financial and courier services has an important impact on the country's participation in GVCs at a significance level of 5\%, logistics and professional services at a significance level of $10 \%$.

Then the coefficients of correlation between the country's participation index in the GVC and the values of statistically significant regressors were calculated. The results are shown in Table 1.

Table 1. Coefficients of Correlation between the Index of Participation in the GVC and the Services Restrictive Index by Sectors

\begin{tabular}{|l|c|}
\hline & Index of Participation in the GVC \\
\hline Financial services & -0.26 \\
\hline Telecommunications & -0.32 \\
\hline Courier services & -0.33 \\
\hline Logistics & -0.25 \\
\hline Professional Services & 0.25 \\
\hline
\end{tabular}

Source: Calculated by the authors.

Table 1 shows that barriers in all service sectors excluding professional services have a negative impact on the participation of countries in the GVC. The positive value of the coefficient of correlation for professional services may be a consequence of the overall level of restrictiveness in this industry due to the complexity of licensing the 
activities of foreign service providers [Geloso Grosso, Gonzales, Miroudot et al., 2015, p. 12]. Indeed, the greatest number of differences in the legislation of the countries of the European Union, where the greatest success in the formation of a single market for services has been achieved, remains in the field of recognition of foreign professional diplomas. Thus, it can be concluded that there is an inverse relationship between the level of barriers to the infrastructure services and a country's participation in the GVC. Thus, liberalization of the service sector can become one of the factors for the successful integration of countries into the GVC. However, liberalization of trade in services requires considerable preliminary work to ensure that the process is effective.

\section{BRICS Participation in Global Value Chains: Main Features}

To determine the degree of participation, as well as the possibility of deepening the integration of the BRICS countries into the GVC through the liberalization of the services sector, we use the approach developed by the United Nations Conference on Trade and Development (UNCTAD). This approach is based on the assessment of the manufacturability of industrial exports (including both components and finished products) and the share of services in the total exports of countries.

To begin, it is worth describing the degree of involvement of the BRICS countries in global value chains using the index of participation in the GVC. The values of the index are shown in Table 2.

Table 2. Indices of Participation of the BRICS Countries in the GVC $(2011, \%)$

\begin{tabular}{|l|c|c|c|c|}
\hline & Forward Linkages & $\begin{array}{c}\text { Backward } \\
\text { Linkages }\end{array}$ & $\begin{array}{c}\text { Index of } \\
\text { Participation } \\
\text { in GVCs }\end{array}$ & $\begin{array}{c}\text { Ratio of Forward Linkages / } \\
\text { Backward Linkages }\end{array}$ \\
\hline Brazil & 10.77 & 24.5 & 35.27 & 0.44 \\
\hline China & 32.16 & 15.6 & 47.76 & 2.06 \\
\hline India & 24.1 & 19.1 & 43.2 & 1.26 \\
\hline Russia & 13.72 & 38.1 & 51.82 & 0.36 \\
\hline South Africa & 19.47 & 26.5 & 45.97 & 0.73 \\
\hline
\end{tabular}

Source: “OECD Trade in Value Added (TiVA).” www.stats.oecd.org (April 2017).

Concerning the nature of the country's participation in the GVC, the ratio of the share of foreign value added in national exports and the share of national value added in the export of third countries is indicative. For the BRICS countries, this indicator is greater than 1 for China and India, each of which uses significant amounts of imported components and intermediate services in the production of final goods and services.

To determine at which stages of the production GVC the BRICS countries create the greatest added value, we analyzed the structure of their exports and imports in terms of value added. 
Of the BRICS countries China is most involved in the system of international production in absolute terms of value added. One-third of Chinese exports consists of the added value of imported intermediate goods and services. The most strongly foreign component is expressed in the cost of production of electronic industry and telecommunications equipment - the main article of Chinese exports - as well as electrical equipment. In addition, in the textile industry and trade - the second and third largest export sectors - the value added generated by China accounts for $95.9 \%$ and $73.5 \%$, respectively [OECD and WTO, 2015b].

The services sector accounts for about $40 \%$ of total Chinese exports. At the same time, China is the only BRICS country in which the predominance of added value is created by services of foreign (17.8\%) over local $(13.3 \%)$ origin in total industrial exports. However, Chinese service providers are increasingly integrated into the GVC as evidenced by the gradual increase in the value added they create in services value chains [OECD and WTO, 2015b].

A distinctive feature of the Indian economy is that over the past 20 years it has set a record pace among BRICS countries for integration into the GVC - the share of foreign components in exports increased from $10 \%$ in 1995 to $24 \%$ in 2011 . In many ways, such rapid growth can be explained by the country's specialization in services, which account for $57.5 \%$ of total Indian exports in terms of value added [OECD and WTO, 2015c]. The main export industries are trade, transport-warehouse services and products of oil refining. From the point of view of the country of origin that generates value added services in total exports, Indian intermediate service providers account for 47.8\%, while foreign suppliers account for 9.7\% [OECD and WTO, 2015c].

Of BRICS countries, Brazil has the largest share of the national value added in total exports (about 90\%), although the export orientation of Brazilian industry is much lower than the average for the BRICS countries [OECD and WTO, 2015a]. Brazil's main export items are the products of the extractive and food industries, as well as trade. The national component of the added value of exports is created predominantly in the extractive industry and services $(90 \%)$, while services account for one-third of the value added in industrial exports. The share of services of foreign suppliers is relatively small and amounts to about $10 \%$ in total exports [OECD, WTO, 2015a]. The main trading partner of Brazil is China; the share of Latin American countries in the geographical structure of Brazilian exports is relatively small and indicates the insufficient development of value chains in the region.

Russia's participation in the GVC is also characterized by the predominant share of the national value added in total exports due to the significant resource orientation of the economy. The main export items are products of the extractive (including oil) and metallurgical industries. The sectors most involved in international production are oil production and refining, ferrous and non-ferrous metallurgy, the chemical industry and machine building [Kadochnikov, 2015]. Services create $42.5 \%$ of the value of total exports, which is comparatively lower than the average in developed countries $(54.3 \%)$. At the same time, foreign and national service providers account for $6.6 \%$ and $28.1 \%$ respectively [OECD, WTO 2015d]. 
South Africa, like Brazil and Russia, is involved in international production as a supplier of raw materials and intermediate products with a low degree of processing, while China and India are the main importers within the GVC. The share of services, mainly of national origin, accounts for $44.8 \%$ of the total value of exports [OECD, WTO 2015e (May 2017)].

Thus, the nature of the participation of the BRICS countries in GVCs is not uniform. Brazil, Russia and South Africa are involved in the GVC as suppliers of raw materials and intermediate goods, while China and India are active importers of foreign components and intermediate services for use in further production processes.

To appreciate the depth of integration of a country in the GVC, the length of production chains in which countries participate is indicative. From 1995 to 2009, China increased its participation in complex highly fragmented chains that resulted in involvement in more technological production chains and diversification of products. Contrary to this, the length of the GVC in which the rest of the BRICS countries were involved either remained the same or decreased slightly due to export specialization in a narrow range of industries which concentrated almost all the value added created in these countries.

Additionally, the structure of services exports of BRICS countries is very heterogeneous. According to the data on trade in the OECD in value added terms, China is the absolute leader in the export of services with a volume more than twice that of India. The lowest volume of services exports is observed in South Africa, where most of the value added is in trade, hotel services, restaurants and financial services. The main item of Russian services exports in addition to trade is transport and warehousing services, while its volume of exports of advanced computer technologies is the lowest among the BRICS countries. A similar situation is observed in the structure of Brazil's exports. As for the services involved in the production GVC, their distribution in terms of manufacturability is very different: the most technological structure is in China and India, with the least technological structure in Brazil, Russia and South Africa [UNCTAD, 2013]. Thus, Russia, Brazil and South Africa have a significant potential to expand their participation in production and services GVCs through the development of the services sector. As noted previously, barriers to services in the BRICS countries are much higher than in developed countries. Thus, the liberalization of trade in services could bring significant benefits, including improving the quality and level of manufacturability of exported services.

\section{Specificity of Services Liberalization in the BRICS Countries}

The volume of value added exported by the BRICS countries has increased over the past twenty years. China and India have demonstrated outstanding growth rates - their exports increased by six and five times respectively - while the value added exported by Russia, Brazil and South Africa grew more slowly.

One of the factors that led to the active integration of the Chinese and Indian economies into global value chains was the liberalization of particular service sectors 
with the aim of boosting the efficiency of local service providers through increased competition in the domestic market.

In this respect, the most revealing example is the liberalization of the Indian service sector, completely closed until the 1980s and characterized by the dominance of state-owned companies and high-entry barriers for both foreign and local private firms. Since the 1990s numerous reforms have been carried out to liberalize the service sector under a comprehensive economic restructuring programme supported by the International Monetary Fund.

A particularly strong influence on India's participation in the GVC was the liberalization of telecommunications and transportation infrastructure services controlled by the state under a planned economy. Only two state-owned companies had the right to carry out air transportation and the shipping sector was practically closed to private firms; the state monopoly extended to the telecommunications sector as well [Matthias, Javorcik and Mattoo, 2016, p. 5]. However, insufficient resources meant the state was unable to improve the quality of services and the efficiency of the sector. This was the main reason for its liberalization in the early-1990s.

The main liberalization measures were privatization and facilitation of market-entry procedures for local firms, as well as the lifting of restrictions on the activities of foreign companies. The most profound liberalization occurred in the telecommunications sector, where all barriers were eliminated for both local and foreign service providers.

The reduction in prices for transport services and the improvement of transport infrastructure led to lower costs, a prerequisite for increasing the export potential of Indian enterprises. Thus, the liberalization of infrastructure services contributed to an annual increase in industrial output of 5.7\% from 1993 to 2005 and to a large extent determined the integration of India into the production GVC.

In turn, the level of competition in the Indian market increased significantly, which led to an improvement in the quality of transport and telecommunications services and a reduction in prices. Another important consequence was the inflow of FDI indispensable for technological improvement of the industry. From 1992 to 2002 FDI in the services sector grew by $36 \%$ annually, outpacing the growth rate of investment in industry by $16 \%$ [Bas, 2014, p. 552]. At the same time, the largest volume of foreign investment was accounted for by the telecommunications sector. FDI also contributed to the development of technology-based services. The growth rate of the Indian information and communications technology (ICT) services sector is now among the highest in the world and the volume of export of ICT services is less only than China's [Biryukova and Matyukhina, 2016, p. 46].

The most attractive services sectors for foreign capital are finance and insurance, technical services and telecommunications, as well as services related to research and development. Outsourcing remains an important form of inclusion for India in global value chains.

Scientific and technological projects are a priority of Indian state policy. In recent years the state has been pursuing policy aimed at increasing the innovative activity of the private sector involving foreign capital. State and private organizations engaged in the 
patenting and commercialization of innovations have been actively supported. Among such organizations are the Indian Technology Development Fund, the Indian Venture Capital Association, the National Venture Fund of for Software and Information Technology and others. [Galischeva, 2015]. An important element of India's innovation system is the network of technoparks to support the development of high-tech exports. Thus, the Indian government consistently pursues a policy of innovative development aimed at expanding the role of the corporate sector.

The beginning of services liberalization in China in the 1990s was associated with the beginning of negotiations on China's accession to the World Trade Organization (WTO). Nevertheless, regarding the existing political regime and state regulation of the economy, the scope of services liberalization in China is limited. However, there are examples of the positive impact of individual service sectors liberalization on their effectiveness. For example, in the telecommunications services sector foreign firms were permitted to enter the market through equity participation in state companies and a law banning monopolies in this sector was passed in 2002. [Bas and Causa, 2013, p. 846]. As a result of increased competition, China's telecommunications services sector began to grow at an impressive pace and today is the largest in the world.

Another example of the linkage between the quality of infrastructure services in a country and its participation in the GVC is the transport sector in China. The predominance of state-owned enterprises, low levels of competition and significant restrictions on the participation of foreign companies in the production of transport services have led to inefficiency in this service sector. There is a significantly uneven development of the transport system in the centre of the country compared to coastal regions, where most export-oriented enterprises are located. With the development of container transportation, the need for a railway network to deliver goods arriving by sea to the central regions has increased. However, due to congestion on railway lines, priority is given to large-tonnage transports carrying goods with lower value added [Hodge, 2002]. This has become a serious obstacle to China's integration within more lucrative GVCs.

The liberalization of the Chinese financial sector is of particular interest. In the 1990s only four commercial banks operated in the financial services market, and these were accountable to the People's Bank of China which dominated the sector. In the process of accession to the WTO, China has undertaken a limited number of commitments in relation to eight of the 12 financial services subsectors [WTO, Trade Policy Review, 2016]. These commitments include reducing entry barriers for private Chinese and foreign banks, increasing the transparency of the loan system and a number of other measures that facilitate the integration of the Chinese financial services market into the international market. However, these measures do not exclude state regulation of the financial services sector, which is still widely implemented. It is worth noting that developing countries are inclined to take on limited commitments within the WTO in the financial services sector. This is also true for India, where there are quantitative restrictions on the capital and affiliates of foreign financial companies. The services sector and trade were identified as a priority strategic direction in the 12th five-year plan (2011-2015). The Chinese government planned to spur the development of key 
services sectors including finance, logistics, education and health. The goal of the government was to take a leading place among the largest exporters of transport, tourism, construction services as well as other subsectors of services for which comparative advantages were revealed. The plan envisaged joint work on the programme concerning foreign trade in goods and services, as well as enhancing technological and knowledgeintensive components of foreign trade.

As a result of the implementation of the five-year plan, growth rates in the Chinese service sector increased, but they were significantly lower than expected. To develop the enormous potential of the services sector it is necessary to strengthen the business sector, ensure workspace for a quickly growing workforce, facilitate terms of trade, accelerate the introduction of advanced management practices and improve overall economic efficiency.

The most vivid example of liberalization of infrastructure services in Brazil is rail transportation. In the 1990s the state railways of Brazil were privatized through concession agreements with private companies. As a result, the volume of rail traffic increased by $90 \%$ between 1996 and 2003 [Soliani, 2015, p. 257]. The increase in demand was largely due to the growth of the agricultural sector and the development of intermodal transport. Presently, despite the considerable territory of the country, Brazilian railways are only tenth in the world, notably behind India, Russia and China. From 1997-2000, Brazil occupied the first place in income from transfer of property to the private sector; the privatization of Telebras was the largest privatization operation in Latin America and the third largest in the world. The most important result of the privatization policy was the qualitative improvement in the conditions of many services sector branches, primarily ICT. In Brazil, many firms of the services sector that initially attracted foreign investments have over time become exporters of services, thereby demonstrating the importance of "compatibility" and complementarities to increasing exports [Francois and Hoekman, 2010]. The experience of Brazil is an example of how trade in services through commercial presence (the third way of supply) can have a stimulating effect on cross-border trade (the first way of delivery). From 1990-2007, the average annual increase in exports of services to Brazil was $14 \%$ while the global growth was $9 \%$. The subsequent internationalization of services, carried out mainly by new and small companies in the ICT sector, was caused by the growing demand from the companies of the first wave of internationalization for integrated software frameworks, data processing and storage, software development and the creation of network services. Thus, foreign direct investment has become a foundation for the subsequent expansion of export of services.

Significant liberalization of the infrastructure services sector in Russia is linked to the country's ascension to the WTO in 2012. Russia took commitments in 116 services sectors. For example, in the banking system the overall foreign capital participation is limited to $50 \%$ (not including foreign capital invested in potentially privatized banks). Moreover, a nine-year transition period was established, after which foreign insurance companies will have an opportunity to open branches in Russia [Zuev, Birjukova, Meshkova et al., 2016]. A transition period was also established for the telecommuni- 
cations services sector, which should meet the standards of the General Agreement on Trade in Services in four years. As for the commitments taken by Russia in the transport services sector, almost all of them comply with current legislation and therefore no fundamental changes in the regulation system for transport services were required. In 2014, several countries imposed sanctions against Russia that inevitably affected the investment flows of the country and its involvement in the GVC. The situation was further aggravated by the depreciation of the ruble and other macroeconomic factors. Sanctions resulted in restricted access to international financial markets for some Russian banks and companies which made external borrowing very expensive. Weak expectations held by national businesses and consumers regarding future growth reduced the total volume of investment, and massive export of capital made the currency market more volatile and accelerated the ruble's decline.

Share of the service sector shows a steady upward trend in the structure of accumulated direct investments. However, such growth is caused by the attractiveness of fast-paying and low-technology industries and trade primarily for foreign investors. At the same time, Russia has a relatively low volume of direct investment to scienceintensive services and transport.

The domestic services sector requires active policy to attract investments with the aim of increasing competition in the local market, to attract financial resources and technologies and to improve the quality of services provided. At the same time, it is important to develop programmes to attract capital to more complex, knowledge-intensive sectors of the service sector. This, in our opinion, could be business services, financial services, information and communication or research and development, including through integration into value chains. The development of these types of services positively influences the welfare of end users, increases the efficiency of industrial production and ultimately improves the performance of the real sector of the economy.

The South African service sector is one of the most developed on the continent and is relatively open to the BRICS countries. Today, South Africa is the main provider of financial services in the region, as it has a comparative advantage over its less developed neighbours.

However, the liberalization of South Africa's services sector has faced difficulties caused by an imperfect institutional structure and the characteristics of the market system in the country. For example, budget policy priorities hampered privatization processes, while liberalization of the transport sector was postponed for several years due to the large debt of state transport enterprises [Hodge, 2002] which contributed to the slowed development of transport infrastructure in the country. In 2006, South Africa signed an agreement with the International Telecommunications Union according to which, by 1 June 2015, there was to be a transition from analogue to digital broadcasting. However, South Africa did not complete the transition until mid-2017, which prevented the creation of an infrastructure for broadband mobile networks for a new generation.

Although South Africa is relatively open to foreign direct investment, new projects, mergers and acquisitions are being tested for possible effects on employment and 
local production. The private sector is considerably concerned about the expansion of the role of the state in this sphere. Significant restrictions on foreign investors have affected telecommunications. For example, in 2016, the Communications Regulator of South Africa decided that the foreign share of the broadcasting services sector should not exceed $20 \%$. There is a requirement for a fixed national share in the subscriber services of satellite, cable and regular communications in television and radio broadcasting in South Africa.

Thus, after analysing the experience of the BRICS countries, it is possible to identify some features that are typical of the process of services liberalization in these countries. In general, the liberalization of infrastructure services has a significant and positive impact on the efficiency of both production and service sectors. Nevertheless, the BRICS countries continue to be much more closed than the developed ones for several reasons. First, the imperfect market system in developing countries can have negative consequences for the economic stability of the country when the service sector is liberalized. Second, local producers and service providers may be in a worse position due to competition from foreign companies. Third, the features of the political regime and national specifics play an important role. In many respects, it is the desire to protect its interests from the imbalances that arise between developed and developing countries as a result of the elimination of barriers to services which underlies the refusal of the BRICS countries to participate in the Agreement on Trade in Services initiated in 2012 by the United States within the WTO, intended to deepen multilateral liberalization of trade in services between the informal group of member countries of the organization [Biryukova, 2013].

\section{Ways to Increase the BRICS Countries' Integration in GVCs}

Having analysed the participation of BRICS countries in global production and service value chains and the possibilities and limitations of specific services sector liberalization, it is possible to identify key measures aimed at encouraging further integration of these economies into the GVC system.

BRICS countries face different challenges in the context of their participation in GVCs. China, the BRICS country most integrated into production and service value chains, is interested in enhancing value added by increasing the technological intensity of production stages and complexity of the GVC. The same purpose with respect to the service GVC is relevant for India. Being the second service provider after China, it can significantly increase the profitability of value chains through promoting the production of knowledge-intensive services such as professional and ICT services. At the same time, China and India each have significant resource potential in the form of highly skilled workforces and requisite financial resources. Thus, China is the largest FDI host country among developing countries (figures for 2015 amounted to $\$ 136$ trillion). India is also among the top twenty recipient countries with FDI of $\$ 44$ trillion [UNCTAD, World Investment Report 2013, p. 256]. 
Russia, Brazil and South Africa's interests at this stage mainly lie in export diversification and increasing backward participation, i.e., the share of foreign components in exports. This will help these countries to shift from a focused resource-based model to the production of components and final use products with higher value added and increased attractiveness to foreign investors.

Global value chains in today's global economy are based on foreign direct investment and the activities of transnational corporations (TNCs), which are now the key players in the world economy. Therefore, countries that seek to more actively integrate into GVCs need to adopt a consistent and competent policy regarding foreign capital. It is important to maintain a balance between potential benefits from solutions to national economic problems and possible threats of excessive vulnerability caused by uncontrolled access of foreign investors to the country's resources.

For the development of GVCs it is important to overcome the gap between suppliers and distance to the market. This can only be achieved by reducing transport costs and increasing the efficiency of operations in border areas as well as the development of information technologies [Klochko, 2017].

To actively participate in GVCs a country should have a well-developed logistics infrastructure, including a variety of sectors and subsectors (cargo handling, storage, warehousing, agency and related support services, freight transportation, air, rail, sea, express services and courier) and should consistently take action on trade facilitation (in the first place, to simplify customs and border procedures) [Biryukova, 2016, p. 122]. In turn, the development of GVCs in member states contributes to improving the quality of many services including ICT, transport, customs clearance procedures and inventory management systems.

This analysis of the service sector restrictiveness index for the BRICS countries has shown that the liberalization of services, and the infrastructure services sector in particular, might become one of the most effective tools for integration into the GVC. As services are an integral part of both production and service GVCs and enable their functioning, the quality and cost of transport, telecommunications and financial services depend on the efficiency of the entire chain and the size of the value added by a particular firm or the entire economy. Moreover, in the face of declining tariffs for trade in goods, an efficient services sector has become a crucial factor determining the competitiveness of the national economy. Participation in complex service global value chains increases the efficiency of the entire service sector in a country and, therefore, encourages investments and the creation of necessary infrastructure for further integration into the production GVC.

However, it is important to mention that service liberalization itself could have a limited impact on the BRICS countries' integration into GVCs. The reason is that investment decisions are made by foreign companies on the basis of the overall attractiveness of the economy. Thus, without necessary infrastructure, effective state regulation and well-functioning financial and legal systems, significant expansion and deepening of the country's participation in the GVC is highly unlikely. That is why the ways of in- 
creasing a country's involvement in GVCs should include a set of trade and investment policy tools, intellectual property protection measures and reforms aimed at improving the functioning of state institutions.

\section{References}

Bas M. (2014) Does Services Liberalization Affect Manufacturing Firms' Export Performance? Evidence from India. Journal of Comparative Economics, vol. 42, no 3, pp. 569-589.

Bas M., Causa O. (2013) Trade and Product Market Policies in Upstream Sectors and Productivity in Downstream Sectors: Firm-level Evidence from China. Journal of Comparative Economics, vol. 41, no 3, pp. 843-862.

Bhattacharya M. (2016) International Trade and Economic Growth: Evidences From The BRICS. Journal of Applied Economics and Business Research, vol. 6, no 2, pp. 150-160.

Biryukova O.V. (2013) Torgovlja uslugami v Dohijskom raunde: mnogostoronnee soglashenie dlja izbrannyh? [Trade in Services in the Doha Round: a Plurilateral Agreement for the Elite?]. International Organisations Research Journal, vol. 8, no 2, pp. 41-54. (in Russian).

Biryukova O.V. (2016) Uchastie sektora uslug v razvitii global'nyh cepochek sozdanija stoimosti [Participation of the Services Sector in the Development of the Global Value Chains].Izvestiya Uralskogo gosudarstvennogo ekonomicheskogo universiteta. [Journal of the Ural State University of Economics], no 3, pp. 98-110. (In Russian.)

Biryukova O.V., Matiukhina A. I. (2016) Stranyi BRICS na mirovom ryinke IKT-uslug [BRICS Countries in International ICT Services Trade]. Latinskaya Amerika [Latin America], no 9. pp. 41-54. (In Russian.)

Biziwick M., Cattaneo N., Fryer D. (2015)The Rationale for and Potential Role of the BRICS Contingent Reserve Arrangement. South African Journal of International Affairs, vol. 22, no 3, pp. 307-324.

De Castro T. (2012) EU-BRIC Trade Assessment: Introversion, Complementarity and RCA. Scientiaet Societas, vol. 8, no 3, pp. 68-80.

De Castro T. (2013) Trade Among BRICS Countries: Changes Towards Closer Cooperation? Ekonomická Revue, vol. 16, no 3, pp. 131-148.

Elms D.K., Low P. (eds) (2013) Global Value Chains in a Changing World, WTO Publications for Fung Global Institute, Nanyang Technological University and the World Trade Organization, Geneva. Available at: https://www.wto.org/english/res_e/booksp_e/aid4tradeglobalvalue13_e.pdf (accessed 12 April 2017).

Francois J., Hoekman B. (2010) Services Trade and Policy. Journal of Economic Literature, vol. 48, no 3, pp. 642-92.

Galishheva N.V. (2015) Problema disbalansov v jekonomike Indii [The Problem of Imbalances in Indian Economy]. Vestnik MGIMO Universiteta [Vestnik MGIMO-University], vol. 43, no 4, pp. 242-254. (In Russian.)

Geloso Grosso M. et al. (2015) Services Trade Restrictiveness Index (STRI): Scoring and Weighting Methodology, OECD Trade Policy Papers. Available at: http://www.oecd-ilibrary.org/trade/servicestrade-restrictiveness-index-stri_5js7n8wbtk9r-en (accessed 5 May 2017).

Global Value Chain Development Report (2017) Measuring and Analyzing the Impact of GVCs on Economic Development, co-published by the World Bank, WTO, OECD, Institute of Developing Economies (IDE-JETRO) and the Research Centre of Global Value Chains (RCGVC). Available at: https:// www.wto.org/english/res_e/booksp_e/gvcs_report_2017.pdf (accessed 15 July 2017).

Hodge J. (2002) Liberalization of Trade in Services in Developing Countries. Development, Trade and the WTO: A Handbook (B. Hoekman, P. English, A. Mattoo (eds)). Washington, DC: World Bank, pp. 221-234. 
Kadochnkov P.A. (2015) Perspektivnye voprosy rasshirenija uchastija Rossii v global'nyh cepochkah stoimosti [Perspective Issues of the Enlargement of Russian Participation in Global Value Chains]. Rossijskij vneshnejekonomicheskij vestnik [Russian Foreign Economic Journal], no 2, pp. 8-13. (In Russian.)

Khatun R. (2016) Relation Between Trade in Financial Services and Economic Growth in BRICS Economies: Cointegration and Causality Approach. Global Business Review, vol. 17, no 1, pp. 214-225.

Klochko O.A. (2017) Vliyanieregionalnoyintegratsiinaformirovanietsepeypostavok v usloviyahglobalizatsii [Impact of Regional Integration on Creating Supply Chains in a Globalized World]. Logistika i upravlenie tsepyam i postavok [Logistics and supply chain management], vol. 2, no 79, pp. 112-120. (In Russian.)

Knobel' A. Ju. (2012) Vlijanie liberalizacii sektora uslug na torgovlju uslugami i proizvoditel'nost' v promyshlennosti v Rossiii v drugih stranah SNG [The impact of Services Liberalization on Trade in Services and Manufacturing Productivity in Russia and in Other CIS Countries]. Vlijanie liberalizacii sfery uslug na proizvoditel'nost' otrasli, jeksport I razvitie: jempiricheskie issledovanija v stranah s perehodnoj jekonomikoj [The Impact of Services Liberalization on Sector Productivity, Export and Development: Empirical Studies in Transition Economies] (D.G. Tarra ed.). Moscow: Ves' Mir. (in Russian).

Lanz R., Maurer A. (2015) Services and Global Value Chains - Some Evidence on Servicification of Manufacturing and Services Networks. Working Paper ERSD-2015-03. Geneva: WTO.

Larionova M. (2016) Assessing Summit Engagement with Other International Organizations in Global Governance. International Organisations Research Journal, vol. 11, no 1. DOI: 10.17323/1996-7845/2016$01-126$

Matthias J., Javorcik B., Mattoo A. (2016) Services Reform and Manufacturing Performance: Evidence from India. The Economic Journal, vol. 126, no 590, pp. 1-39.

Nil'son Dzh., Taglioni D. (2009) Modelirovanie jekonomicheskih vygod ot liberalizacii torgovl i uslugami [Modelling Economic Benefits of Services Trade Liberalization]. International Organisations Research Journal, vol. 4, no 1, pp. 34-70. (In Russian.)

OECD, WTO (2015a) Country Notes. Trade in value added: Brazil. Available at: https://www.oecd.org/ sti/ind/tiva/CN_2015_Brazil.pdf (accessed 5 May 2017).

OECD, WTO (2015b) Country Notes. Trade in value added: China. Available at: https://www.oecd.org/ sti/ind/tiva/CN_2015_China.pdf (accessed 5 May 2017).

OECD, WTO (2015c) Country Notes. Trade in value added: India. Available at: https://www.oecd.org/ sti/ind/tiva/CN_2015_India.pdf (accessed 5 May 2017).

OECD, WTO (2015d) Country Notes. Trade in value added: Russian Federation. Available at: https:// www.oecd.org/sti/ind/tiva/CN_2015_RussianFederation.pdf (accessed 5 May 2017).

OECD, WTO (2015e) Country Notes.Trade in value added: South Africa. Available at: https://www. oecd.org/sti/ind/tiva/CN_2015_SouthAfrica.pdf (accessed 5 May 2017).

Sharma S.K., Kallummal M. (2012) A GTAP Analysis of the Proposed BRICS Free Trade Agreement // 15th Annual Conference on Global Economic Analysis New Challenges for Global Trade and Sustainable Development, Geneva, Switzerland, June, pp. 27-29.

Soliani R. (2015) Brazilian Road and Rail Transportation Sectors and Its Challenges. International Journal of Business Management and Economic Research (IJBMER), vol. 6, pp. 256-265.

UNCTAD (2013) World Investment Report 2013. Global Value Chains: Investment and Trade for Development. Available at: http://unctad.org/en/PublicationsLibrary/wir2013_en.pdf (accessed 5 May 2017).

WTO (2016) Trade Policy Review: China. World Trade Organization. Available at: https://www.wto.org/ english/tratop_e/tpr_e/s342_e.pdf (accessed 5 May 2017).

Yuan H., Zhao Z. (2011) Comparative Analysis on Foreign Trade of the BRICs. M\&D Forum, pp. 166172. Available at: http://www.seiofbluemountain.com/upload/product/20 1112/2011jjzx05a2.pdf (accessed 5 May 2017).

Zuev V.N. (ed.) (2016) Global'nye instituty regulirovanija: uchebnik [Global Governance Institutions: studybook]. Moscow: Magistr, Infra-M. (In Russian.) 


\title{
Влияние либерализации сферы услуг на участие стран БРИКС в глобальных цепочках добавленной стоимости ${ }^{1}$
}

\author{
О.В. Бирюкова, Т.В. Воробьева
}

Бирюкова Ольга Владимировна - к.э.н., доцент, факультет мировой экономики и мировой политики, старший научный сотрудник Института торговой политики, Национальный исследовательский университет «Высшая школа экономики»; Российская Федерация, Москва, 101000, ул. Мясницкая, д. 20; E-mail: Olga. Birjukova@mail.ru

Воробьева Татьяна Витальевна - учебный ассистент, факультет мировой экономики и мировой политики, Национальный исследовательский университет «Высшая школа экономики»; Российская Федерация, Москва, 101000, ул. Мясницкая, д. 20; E-mail: tatiana_vorobeva@bk.ru

Статья посвящена исследованию характера и степени влияния либерализации сферы услуг на участие стран БРИКС в глобальных цепочках стоимости (ГЦС).

В статье при помощи методов эконометрического анализа была определена обратная взаимосвязь между величиной барьеров в инфраструктурных отраслях услуг и степенью участия стран в глобальных цепочках создания стоимости.

С помощью данных о структуре торговли товарами и услугами в терминах добавленной стоимости было проанализировано положение развивающихся стран на примере стран БРИКС в производственных и сервисных ГЦС. Так, Китай и Индия являются странами, наиболее глубоко вовлеченными в межждународные производственные и сервисные цепочки. Несмотря на то что Россия, Бразилия и Южная Африка включены в производственные цепочки стоимости в большей степени как поставщики сырья и промежуточных товаров с низкой добавленной стоимостью, эти страны обладают значительным потенциалом расширения своего участия в системе международного производства, в частности, посредством улучшения инфраструктуры, необходимой для функционирования ГЦС.

На основе изучения опыта либерализации отдельных секторов услуг в странах БРИКС было выявлено положительное влияние снижения барьеров в сфере морских, железнодорожных и авиаперевозок, а также финансов на улучшение качества и снижение стоимости предоставляемых услуг. Авторы отмечают, что во многом подобные эффекты стали результатом не только снижения барьеров в сфере услуг, но и реализации комплекса мер, направленных на повышение инвестиционной привлекательности стран. В статье сделан вывод, ито либерализация инфраструктурных отраслей услуг может стать одним из инструментов интеграции стран БРИКС в ГЦС. Вместе с тем эта либерализация должна являться элементом более широкой стратегии развития, включающей меры торговой и инвестиционной политики, направленные не только на расширение участия в глобальном производстве, но и общее экономическое развитие страны.

Ключевые слова: глобальные цепочки стоимости; добавленная стоимость; сектор услуг; БРИКС; либерализация

Для цитирования: Бирюкова О.В., Воробьева Т.В. Влияние либерализации сферы услуг на участие стран БРИКС в глобальных цепочках добавленной стоимости // Вестник международных организаций. 2017. T. 12. № 3. C. 94-113. DOI: 10.17323/1996-7845-2017-03-94

${ }^{1}$ Статья поступила в редакцию в июне 2017 г.

Данная работа подготовлена при грантовой поддержке факультета мировой экономики и мировой политики НИУ ВШЭ в 2017 г. 


\section{Литература}

Бирюкова О.В. (2013) Торговля услугами в Дохийском раунде: многостороннее соглашение для избранных? // Вестник международных организаций. Т. 8. № 2. С. 98-110.

Бирюкова О.В. (2016) Участие сектора услуг в развитии глобальных цепочек создания стоимости // Известия Уральского государственного экономического университета. № 3 (65). С. 98-110.

Бирюкова О.В., Матюхина А.И. (2016) Страны BRICS на мировом рынке ИКТ-услуг // Латинская Америка. № 9. С. 41-54.

Галищева Н.В. (2015) Проблема дисбалансов в экономике Индии // Вестник МГИМО Университета. № 4 (43). C. 242-254.

Зуев В.Н. (ред.) (2016) Глобальные институты регулирования: учеб. М.: Магистр; Инфра-М.

Кадочников П.А. (2015) Перспективные вопросы расширения участия России в глобальных цепочках стоимости // Российский внешнеэкономический вестник. № 2. С. 8-13.

Клочко О.А. (2017) Влияние региональной интеграции на формирование цепей поставок в условиях глобализации // Логистика и управление цепями поставок. № 2 (79). С. 112-120.

Кнобель А.Ю. (2012) Влияние либерализации сектора услуг на торговлю услугами и производительность в промышленности в России и в других странах СНГ // Влияние либерализации сферы услуг на производительность отрасли, экспорт и развитие: эмпирические исследования в странах с переходной экономикой / под ред. Д.Г. Тарра. М.: Весь Мир. С. 137-164.

Нильсон Дж., Таглиони Д. (2009) Моделирование экономических выгод от либерализации торговли услугами // Вестник международных организаций. Т. 4. № 1. С. 34-70.

Bas M. (2014) Does Services Liberalization Affect Manufacturing Firms' Export Performance? Evidence from India // Journal of Comparative Economics. Vol. 42. No. 3. P. 569-589.

Bas M., Causa O. (2013) Trade and Product Market Policies in Upstream Sectors and Productivity in Downstream Sectors: Firm-level Evidence from China // Journal of Comparative Economics. Vol. 41. No. 3. P. 843-862.

Bhattacharya M., Bhattacharya S. (2016) International Trade and Economic Growth: Evidences From The BRICS // Journal of Applied Economics and Business Research. Vol. 6. No. 2. P. 150-160.

Biziwick M., Cattaneo N., Fryer D. (2015) The Rationale for and Potential Role of the BRICS Contingent Reserve Arrangement // South African Journal of International Affairs. Vol. 22. No. 3. P. 307-324.

Elms D.K., Low P. (eds) (2013) Global Value Chains in a Changing World, WTO Publications for Fung Global Institute, Nanyang Technological University and the World Trade Organization, Geneva. Режим доступа: https://www.wto.org/english/res_e/booksp_e/aid4tradeglobalvalue13_e.pdf (дата обращения: 12.04.2017).

De Castro T. (2012) EU-BRIC Trade Assessment: Introversion, Complementarity and RCA // Scientia et Societas. Vol. 8. No. 3. P. 68-80.

De Castro T. (2013) Trade Among BRICS Countries: Changes Towards Closer Cooperation? // Ekonomická Revue. Vol. 16. No. 3. P. 131-148.

Francois J., Hoekman B. (2010) Services Trade and Policy // Journal of Economic Literature. Vol. 48. No. 3. P. 642-692.

Geloso Grosso M. et al. (2015) Services Trade Restrictiveness Index (STRI): Scoring and Weighting Methodology, OECD Trade Policy Papers. Режим доступа: http://www.oecd-ilibrary.org/trade/services-trade-restrictiveness-index-stri_5js7n8wbtk9r-en (дата обращения: 05.05.2017).

Global Value Chain Development Report (2017) Measuring and Analyzing the Impact of GVCs on Economic Development, co-published by the World Bank, WTO, OECD, Institute of Developing Economies (IDEJETRO) and the Research Centre of Global Value Chains (RCGVC). Режим доступа: https://www.wto.org/ english/res_e/booksp_e/gvcs_report_2017.pdf (дата обращения: 15.07.2017).

Hodge J. (2002) Liberalization of Trade in Services in Developing Countries // Development, Trade and the WTO: A Handbook / B. Hoekman, P. English, A. Mattoo (eds). Washington, DC: World Bank. P. 221-234. 
Khatun R. (2016) Relation Between Trade in Financial Services and Economic Growth in BRICS Economies: Cointegration and Causality Approach // Global Business Review. Vol. 17. No. 1. P. 214-225.

Lanz R., Maurer A. (2015) Services and Global Value Chains - Some Evidence on Servicification of Manufacturing and Services Networks. Working Paper ERSD-2015-03. Geneva: WTO.

Larionova M. (2016) Assessing Summit Engagement with Other International Organizations in Global Governance // International Organisations Research Journal. Vol. 11. No. 1. DOI: 10.17323/1996-7845/2016-01126

Matthias J., Javorcik B., Mattoo A. (2016) Services Reform and Manufacturing Performance: Evidence from India // The Economic Journal. Vol. 126. No. 590. P. 1-39.

OECD, WTO (2015a) Country Notes. Trade in value added: Brazil. Режим доступа: https://www.oecd.org/ sti/ind/tiva/CN_2015_Brazil.pdf(дата обращения: 05.05.2017).

OECD, WTO (2015b) Country Notes. Trade in value added: China. Режим доступа: https://www.oecd.org/ sti/ind/tiva/CN_2015_China.pdf (дата обращения: 05.05.2017).

OECD, WTO (2015c) Country Notes. Trade in value added: India. Режим доступа: https://www.oecd.org/ sti/ind/tiva/CN_2015_India.pdf (дата обращения: 05.05.2017).

OECD, WTO (2015d) Country Notes. Trade in value added: Russian Federation. Режим доступа: https:// www.oecd.org/sti/ind/tiva/CN_2015_RussianFederation.pdf (дата обращения: 05.05.2017).

OECD, WTO (2015e) Country Notes. Trade in value added: South Africa. Режим доступа: https://www.oecd. org/sti/ind/tiva/CN_2015_SouthAfrica.pdf (дата обращения: 05.05.2017).

Sharma S.K., Kallummal M. (2012) A GTAP Analysis of the Proposed BRICS Free Trade Agreement // 15th Annual Conference on Global Economic Analysis New Challenges for Global Trade and Sustainable Development, Geneva, Switzerland, June. P. 27-29.

Soliani R. (2015) Brazilian Road and Rail Transportation Sectors and Its Challenges // International Journal of Business Management and Economic Research (IJBMER). Vol. 6. P. 256-265.

UNCTAD (2013) World Investment Report 2013. Global Value Chains: Investment and Trade for Development. Режим доступа: http://unctad.org/en/PublicationsLibrary/wir2013_en.pdf (дата обращения: 05.05.2017).

WTO (2016) Trade Policy Review: China. World Trade Organization. Режим доступа: https://www.wto.org/ english/tratop_e/tpr_e/s342_e.pdf (дата обращения: 05.05.2017).

Yuan H., Zhao Z. (2011) Comparative Analysis on Foreign Trade of the BRICs // M\&D Forum. P. 166172. Режим доступа: http://www.seiofbluemountain.com/upload/product/20 1112/2011jjzx05a2.pdf (дата обращения: 05.05.2017). 